\title{
CYP1A1 and GSTP1 polymorphisms in an oral cancer case-control study
}

\footnotetext{
A. Leichsenring ${ }^{1}$,

R. Losi-Guembarovski1,4, M.E. Maciel ${ }^{1}$,

A. Losi-Guembarovski ${ }^{5}$, B.W. Oliveira ${ }^{6}$, G. Ramos ${ }^{6}$, T.C.S. Cavalcanti ${ }^{3,6}$, M.G. Bicalho ${ }^{2}$,

I.J. Cavalli ${ }^{1}$, I.M.S. Cólus ${ }^{4}$ and E.M.S.F. Ribeiro ${ }^{1}$
}

\author{
${ }^{1}$ Laboratório de Citogenética Humana e Oncogenética, \\ ${ }^{2}$ Laboratório de Imunogenética e Histocompatibilidade, \\ Departamento de Genética, ${ }^{3}$ Departamento de Anatomia Patológica, \\ Universidade Federal do Paraná, Curitiba, PR, Brasil \\ ${ }^{4}$ Departamento de Biologia Geral, ${ }^{5}$ Departamento de Patologia Aplicada, \\ Universidade Estadual de Londrina, Londrina, PR, Brasil \\ ${ }^{6}$ Serviço de Cabeça e Pescoço, Hospital Erasto Gaertner, Curitiba, PR, Brasil
}

\author{
Correspondence \\ E.M.S.F. Ribeiro \\ Departamento de Genética \\ Universidade Federal do Paraná \\ Caixa Postal 19071 \\ 81531-970 Curitiba, PR \\ Brasil \\ Fax: +55-41-3361-1555 \\ E-mail: eribeiro@ufpr.br \\ Research supported by Fundação \\ Araucária (Grant 4895 and Pronex) \\ and CNPq.
}

Received March 30, 2006 Accepted September 6, 2006 $\ldots \ldots \ldots \ldots \ldots \ldots$.

\begin{abstract}
CYP1A1 and GSTP1 polymorphisms have been associated with a higher risk to develop several cancers, including oral squamous cell carcinoma (OSCC), which is closely related to tobacco and alcohol consumption. Both genes code for enzymes that have an important role in activating or detoxifying carcinogenic elements found in tobacco and other compounds, and polymorphic variants of these genes may result in alterations of the enzymatic activity. The CYP1A1 gene codes for the enzyme aryl hydrocarbon hydroxylase, which is responsible for the metabolism of polycyclic aromatic hydrocarbons. The investigated polymorphism, Ile/Val, seems to increase the activity of the enzyme in homozygous individuals, leading to an accumulation of carcinogens. The Ile/Val polymorphism occurs because of an $\mathrm{A} \rightarrow \mathrm{G}$ transition at exon 7 , resulting in the $C Y P 1 A 1 * 2 B$ allele. The $G S T P 1 * B$ variant shows an $\mathrm{A} \rightarrow \mathrm{G}$ transition at exon 5, changing the amino acid Ile to $\mathrm{Val}$, with a reduced catalytic activity of the enzyme. Due to this reduction, the carriers of mutant alleles lost the capability to metabolize carcinogens, which could be responsible for a higher susceptibility to cancer. We conducted a case-control study in a group of 72 cases with newly diagnosed OSCC and 60 healthy controls matched for age, gender, smoking habits, and ethnicity. We used PCR methods to identify the allelic variants $C Y P 1 A 1 * 2 B$ and GSTP $1 * B$. The data obtained showed no statistically significant association of allelic or genotypic variants of $C Y P 1 A I * 2 B(\mathrm{OR}=1.06 ; 95 \% \mathrm{CI}=$ $0.49-2.29)$ and $G S T P 1 * B(\mathrm{OR}=1.40 ; 95 \% \mathrm{CI}=0.70-2.79)$ with $\mathrm{OSCC}$.
\end{abstract}

\section{Introduction}

Oral squamous cell carcinoma (OSCC) is highly prevalent among head and neck cancers and is a major cause of cancer morbidity and mortality worldwide. Tobacco and alco-
Key words

- Oral carcinoma

- Biometabolism genes

- CYP1A1

- GSTP1

- Gene polymorphism 
The P450 family comprises at least five subfamilies, designated A to E (1). During biotransformation, the coded enzymes mediate phase I reactions in which xenobiotics are activated to reactive intermediate substances. The CYPIAl gene, located in chromosome 15q22-24 (2), codes for the enzyme aryl hydrocarbon hydroxylase, which is responsible for the metabolism of polycyclic aromatic hydrocarbons present in cigarette smoke, transforming them into carcinogens. Two described polymorphisms, MspI and Ile/Val (or exon 7 polymorphism), seem to increase the activity of the enzyme in homozygous individuals. The Ile/Val polymorphism occurs because of an $\mathrm{A} \rightarrow \mathrm{G}$ transition at position 4889 , resulting in the $C Y P 1 A 1 * 2 B$ allele.

The GST family codes for enzymes that are crucial in the carcinogen detoxification process (phase II), mediating the conjugation of electrophilic compounds with reduced glutathione and facilitating the excretion of many xenobiotics. The enzymes are coded for at least five distinct loci - $\alpha, \mu, \theta, \pi$, and $\gamma$. GSTP1, located in chromosome 11q18 (3), may be of particular relevance for cancer susceptibility. Board et al. (4) described three different alleles: GSTPI*A (wild type), $G S T P 1 * B$ and $G S T P 1 * C$. The GSTP $1 * B$ variant shows an $\mathrm{A} \rightarrow \mathrm{G}$ transition at position +313 , codon 105 , exon 5, changing the amino acid Ile to Val. The $G S T P 1 * C$ allele has 2 transitions, the same as those observed in the GSTP $1 * B$ allele and a second one, located at position +314 , codon 106 , exon 6 , changing the amino acid Ala to $\mathrm{Val}$. The $\mathrm{Ile}_{105} \rightarrow \mathrm{Val}_{105}$ substitution in the $* B$ and $* C$ variants reduces the catalytic activity of the enzyme (5). Due to this reduction in enzyme activity, the carriers of mutant alleles lost the capability to metabolize carcinogens, which could be responsible for a higher susceptibility to cancer.

In the present study, we analyzed two polymorphisms, CYP1A1 Ile/Val and GSTPI $B s m a I$, in order to obtain the gene frequen- cies in a south Brazilian sample, conducting a case-control study to determine if there is an association between these markers and oral cancer.

\section{Material and Methods}

\section{Human subjects}

The patients $(\mathrm{N}=72 ; 61$ males and 11 females, mean \pm SD age $57.26 \pm 11.43$ years) were recruited from Erasto Gaertner Hospital (Curitiba, south of Brazil), Instituto do Câncer de Londrina and Centro Odontológico Universitário Norte do Paraná (Londrina, south of Brazil), centers specializing in the treatment of cancer, between July 2002 and November 2004. The study was approved by the local Ethics Committee. The patients and controls signed informed consent documents and answered a questionnaire about their life style, socioeconomic level, ethnicity, age, occupation, and family history of cancer, among other questions. Also, they had to fulfill the following inclusion criteria: absence of previous radiotherapy or chemotherapy and confirmation of OSCC by anatomopathologic study. Among the controls $(\mathrm{N}=60 ; 49$ males and 11 females, median age $53.68 \pm 12.07$ years), individuals with a history of any malignant disease were excluded from the study.

\section{Laboratory methods}

DNA was extracted by a salting-out method (6). PCR primers were designed according to the Genome Data Bank (GDB; Table 1).

CYP1A1 Ile/Val polymorphism. Allelespecific PCR was performed as follows: 100 $\mathrm{ng} / \mu \mathrm{L}$ DNA was amplified in a total reaction volume of $50 \mu \mathrm{L}$ containing $20 \mathrm{mM}$ Tris$\mathrm{HCl}, 50 \mathrm{mM} \mathrm{KCl}, 1.5 \mathrm{mM} \mathrm{MgCl}, 2 \mathrm{mM}$ of each deoxynucleotide triphosphate, $100 \mathrm{ng} /$ $\mu \mathrm{L}$ of each primer $(\mathrm{W}+\mathrm{A}$ or $\mathrm{W}+\mathrm{G})$, and 1.25 U of AmpliTaq DNA polymerase. PCR 
was carried out in an Eppendorf Gradient Thermocycler after 5 min of pretreatment at $94^{\circ} \mathrm{C}$, with 30 cycles of $1 \mathrm{~min}$ at $94^{\circ} \mathrm{C}$ and 2 min at $70^{\circ} \mathrm{C}$, followed by $5 \mathrm{~min}$ at $72^{\circ} \mathrm{C}$. PCR products $(20 \mu \mathrm{L})$ were subjected to electrophoresis on $2 \%$ agarose gel at $100 \mathrm{~V}$ for 50 min and visualized using ethidium bromide. The primers, named A and G, only differ in one base (A or $\mathrm{G}$ - reflecting the polymorphism) were used in two different reactions with the reverse wild primer (W), yielding fragments with the same molecular weight (340 bp). In Figure 1 we can see two lines for each individual, the first one showing amplification of the wild allele (Ile) and the second the variant allele (Val).

GSTP1 BsmaI polymorphism. The PCRRFLP method was applied as follows: 100 $\mathrm{ng} / \mathrm{LL}$ DNA was amplified in a total reaction volume of $25 \mu \mathrm{L}$ containing $20 \mathrm{mM}$ Tris$\mathrm{HCl}, 50 \mathrm{mM} \mathrm{KCl}, 1.5 \mathrm{mM} \mathrm{MgCl}_{2}, 2 \mathrm{mM}$ of each deoxynucleotide triphosphate, $100 \mathrm{ng} /$ $\mu \mathrm{L}$ of each primer (P105F and P105R), and 1.25 U AmpliTaq DNA polymerase. PCR was carried out in an Eppendorf Gradient Thermocycler, with $5 \mathrm{~min}$ of pretreatment at $95^{\circ} \mathrm{C}, 30$ cycles of $30 \mathrm{~s}$ at $57^{\circ} \mathrm{C}, 30 \mathrm{~s}$ at $72^{\circ} \mathrm{C}$, and $30 \mathrm{~s}$ at $94^{\circ} \mathrm{C}$, followed by $5 \mathrm{~min}$ at $72^{\circ} \mathrm{C}$. After amplification, PCR products $(20 \mu \mathrm{L})$ were cleaved by $5 \mathrm{U} \mathrm{BsmaI}$ enzyme at $55^{\circ} \mathrm{C}$ for $2 \mathrm{~h}$ and then subjected to electrophoresis on $3.5 \%$ agarose gel at $40 \mathrm{~V}$ for $2 \mathrm{~h}$ and visualized using ethidium bromide. The primers P105F and P105R generated an amplified fragment of $176 \mathrm{bp}$ corresponding to the wild genotype (Ile/Ile). After cleavage with the restriction enzyme BsmaI, individuals with the variant allele (Ile/Val) will show two bands of 85 and $91 \mathrm{bp}$, respectively. Figure 2 shows that individual number 1 has both alleles cleaved (mutant homozygote) showing two bands (81 and $91 \mathrm{bp}$ ), 2 and 4 have only one allele cleaved (heterozygotes) showing three bands (176, 91, and $81 \mathrm{bp}$ ), and number 3 has no alleles cleaved (wild homozygote) showing a 176bp fragment.

\begin{tabular}{lll}
$l l l$ & \multicolumn{3}{l}{ Table 1. Oligonucleotide primers used in this study. } \\
\hline Gene & Primer & Sequence \\
\hline CYP1A1 & W & 5'-GAA AGG CTG GGT CCA CCC TCT-3' \\
& A & 5'-AAG ACC TCC CAG CGG GCA AT-3' \\
& G & 5'-AAG ACC TCC CAG CGG GCA AC-3' \\
GSTP1 & P105F & 5'-ACC CCA GGG CTC TAT GGG AA-3' \\
& P105R & 5'-TGA GGG CAC AAG AAG CCC CT-3' \\
\end{tabular}

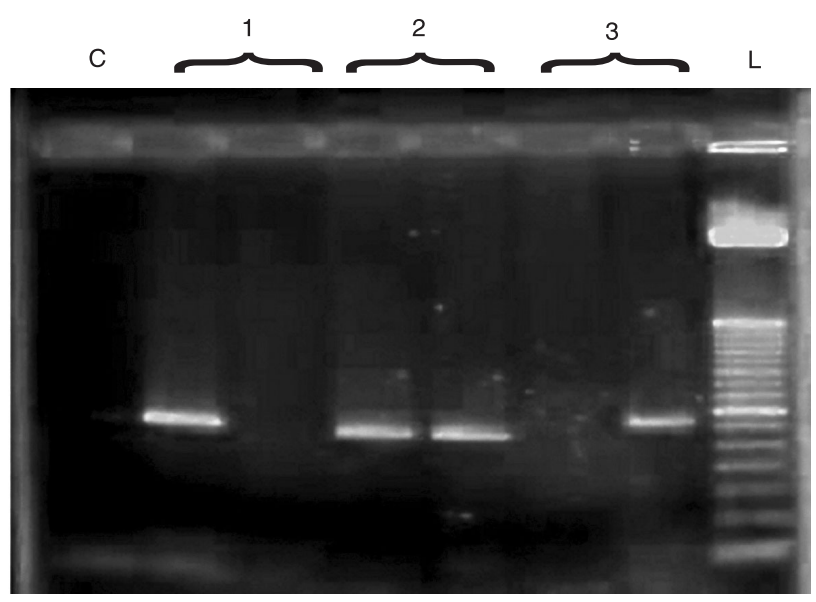

$340 \mathrm{bp}$

Figure 1. Banding pattern of Ile/Val polymorphism (CYP1A1 gene). $\mathrm{L}=$ ladder, $50 \mathrm{bp} ; \mathrm{C}=$ negative control; $1=$ wild homozygote $; 2=\mathrm{lle} / \mathrm{Val}$ heterozygote $3=$ $\mathrm{Val} / \mathrm{Val}$ mutant homozygote.

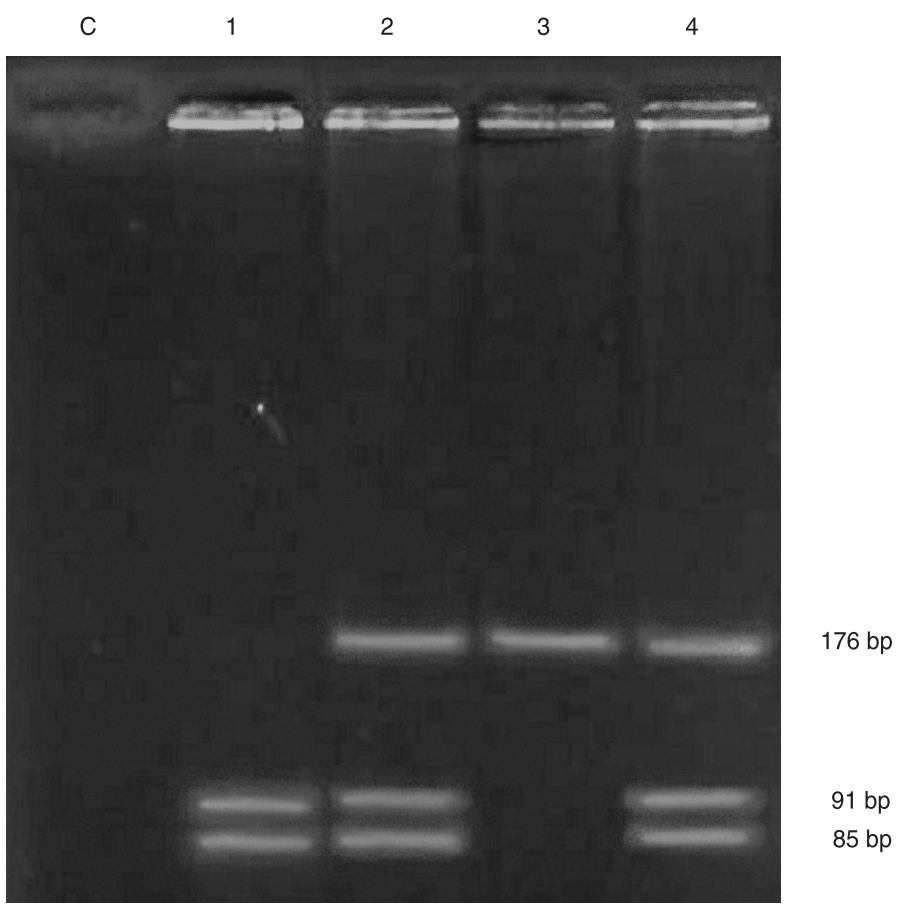

Figure 2. Banding pattern of Bsmal polymorphism (GSTP1 gene). $C=$ negative control; 1 = mutant homozygote; 2 and 4 = heterozygotes; 3 = wild homozygote. 


\section{Statistical analysis}

Statistical analysis was carried out by comparing the allelic frequencies of the CYPIAI and GSTP1 genes between patients with OSCC and controls through a $2 \times 2$ contingency table in order to obtain the $\mathrm{P}$ value. This value was obtained by the Fisher exact test with the RxC program (7). A $\mathrm{P}$ value of 0.05 was adopted as significant. The genotypic frequencies observed were also compared with the expected ones based on the Hardy-Weinberg theorem. The chi-square test for homogeneity was applied in order to verify whether males and females were equally distributed among patients and controls, whether the observed genotypes were equally distributed among patients and controls, and in comparison with other studies.

\section{Results}

Males (61 patients and 49 controls) and females (11 in each group) were homogeneously distributed among the patient and control groups $\left(\chi^{2}{ }_{1}=0.22 ; \mathrm{P}>0.50\right)$. Among the 72 patients analyzed for the CYPIAl gene, 52 had the Ile/Ile genotype, 18 the Ile/ Val genotype and 2 the Val/Val genotype. Of the 60 controls analyzed for the CYP1A1 gene, 44 men had the Ile/Ile genotype and 16 had the Ile/Val genotype. The Val/Val genotype was not detected $\left(\chi_{2}^{2}=1.72 ; \mathrm{P}>0.30\right)$. For the GSTP1 gene, 30 patients were $+/+$, $34+/-$, and 8 -/-. Of the controls, 30 were $+/+, 25+/-$, and 5 -/- $\left(\chi_{2}^{2}=0.98 ; \mathrm{P}>0.50\right)$.

The allelic frequencies of the mutant variants $C Y P 1 A 1 * 2 B$ and $G S T P 1 * B$ were 0.15 and 0.35 , respectively, in the patient group and 0.13 and 0.29 among the controls, resulting in a total frequency of 0.14 for the $C Y P 1 A 1 * 2 B$ allele and of 0.32 for the $G S T P 1 * B$ allele considering the patient and control groups as a whole. The genotypic frequencies observed in both groups were also in Hardy-Weinberg equilibrium, showing that the studied samples were obtained from a population in genetic equilibrium.

The frequencies observed in patients and controls considering both genes together did not demonstrate any significant difference $\left(\chi_{8}^{2}=10.25 ; \mathrm{P}>0.20\right)$.

The association study did not demonstrate a significant association between the genotypes studied and OSCC (CYPIAl polymorphism: $\mathrm{OR}=1.06,95 \% \mathrm{CI}=0.49-2.29$; GSTP1 polymorphism: $\mathrm{OR}=1.40,95 \% \mathrm{CI}=$ 0.70-2.79).

\section{Discussion}

Among malignant diseases, those of epithelial cells contribute to most of the deaths due to cancer worldwide. The association between squamous cell carcinoma of the head and neck (SCCHN) and tobacco has been recognized for a long time and available molecular data suggest that these carcinogens play an important role in malignant transformation. Although these carcinogens may cause a variety of distinct genetic alterations important for the development of SCCHN (8), there is evidence that biometabolism genes may play a significant role in the transformation of benign oral lesions to malignant ones (9).

The $C Y P 1 A 1 * 2 B$ allele is related to increased susceptibility to the development of lung cancer in Japanese (10) and NorthAmerican (11) populations. GSTP $1 * B$ is associated with an increased risk to develop several types of cancer, including those of the bladder, testicles and prostate (12), larynx and pharynx (13), and lung (14).

We did not find a significant association between oral cancer and the CYPIAI (OR = 1.06, 95\% CI: 0.49-2.29) and GSTP1 (OR = 1.40, 95\% CI: 0.70-2.79) genotypes. This result is in agreement with Olshan et al. (15), Ophuis et al. (16), and Xie et al. (17), but not with Park et al. (18), who concluded that the Ile/Val polymorphism is associated with an increased risk to develop OSCC. Although the great majority of studies do not demon- 
strate a significant association between the Ile/Val polymorphism and OSCC, it is important to emphasize that the biometabolism genes do not act alone in an isolated manner. The evaluation of multiple genes interacting amongst themselves and after exposure to different carcinogens may also be necessary for a better understanding of this phenomenon. We performed a homogeneity test in order to evaluate the significance of the differences in haplotype frequencies (CYPIAI/ GSTP1) between patients and controls. No significant difference was found $\left(\chi^{2}{ }_{8}=10.25\right.$; $\mathrm{P}>0.20$ ).

Olshan et al. (15) also demonstrated the absence of any additive or multiplicative interaction between the same genotypes and OSCC, in relation to the GSTPI genotype alone and SCCHN. We also did not verify any significant evidence of association between the GSTP 1 variants and OSCC $(\mathrm{OR}=$ 1.40; 95\% CI: 0.70-2.79). Similar data can be found in a meta-analysis performed by Hashibe et al. (19). Previous studies, like those conducted by Katoh et al. (20) and Park et al. (21) have shown an elevated risk to develop OSCC in individuals with the $G S T P 1 * B$ allele, especially in homozygous individuals.

In our study only seven individuals in the patient group were nonsmokers and the data were insufficient to provide any consistent information about the relationship between tobacco and the development of OSCC among the distinct genotypes.

Besides the divergences found among the studies that search for the association of the GSTP $1 * B$ allele and OSCC, new divergences are arising considering the same allele and other anatomic regions (Ryberg et al. (14); Schneider et al. (22); Abbas et al. (23); Chen et al. (24)). It should be kept in mind that one major factor contributing to the discrepancies found in the analysis of case-control studies could be the interindi- vidual variability in the levels of enzymatic expression. The enzymatic activity of the GST enzymes varies dramatically among individuals in both normal and cancerous tissues and among tissues in the head and neck. There is also evidence that the methylation level in the promoter region of GSTP1 is increased in prostate, liver and breast tumors (25). Thus, epigenetic alterations and other factors could be altering the expression of carcinogen-metabolizing enzymes in different individuals and in different ways. The risks associated with the specific genotypes analyzed in these studies may be obscured by these factors. The same could be valid for $C Y P 1 A 1$ expression and at this time the CYP1A1 genotype/phenotype relationship is poorly understood.

Another important cause of the divergences between different studies may be the presence of false-positive results due to bias (error type I) or to the lack of statistical power (error type II) in studies with reduced sample sizes or with inadequate controls (26,27). Unfortunately, most of the times obtaining an ideal sample size is not possible for a single research group, but even so, according to the same investigators, the results obtained in many studies can contribute enormously to research if analyzed together with the results obtained in other studies. Heterogeneity of risk between different populations could be another reason for divergences, since positive correlations are found in some populations but not in any other worldwide. Finally, the specific pathways for the activation and detoxification of carcinogens in head and neck tissues have not been characterized. Genotype analysis may provide an insight into the role of specific carcinogen pathways. Thus, future studies, including functional analysis, should be carried out, involving sufficiently large samples to allow a more definitive assessment of gene-environment interactions. 


\section{References}

1. Nebert DW, Adesnik M, Coon MJ, Estabrook RW, Gonzalez FJ, Guengerich FP, et al. The P450 gene superfamily: recommended nomenclature. DNA 1987; 6: 1-11.

2. Hildebrand CE, Gonzalez FJ, McBride OW, Nebert DW. Assignment of the human 2,3,7,8-tetrachlorodibenzo-p-dioxin-inducible cytochrome P1-450 gene to chromosome 15. Nucleic Acids Res 1985; 13: 2009-2016.

3. Moscow JA, Townsend AJ, Goldsmith ME, Whang-Peng J, Vickers PJ, Poisson R, et al. Isolation of the human anionic glutathione Stransferase cDNA and the relation of its gene expression to estrogen-receptor content in primary breast cancer. Proc Natl Acad Sci U $S$ A 1988; 85: 6518-6522.

4. Board P, Coggan M, Johnston P, Ross V, Suzuki T, Webb G. Genetic heterogeneity of the human glutathione transferases: a complex of gene families. Pharmacol Ther 1990; 48: 357-369.

5. Pandya U, Srivastava SK, Singhal SS, Pal A, Awasthi S, Zimniak P, et al. Activity of allelic variants of $\mathrm{Pi}$ class human glutathione $\mathrm{S}$ transferase toward chlorambucil. Biochem Biophys Res Commun 2000; 278: 258-262.

6. Miller SA, Dykes DD, Polesky HF. A simple salting out procedure for extracting DNA from human nucleated cells. Nucleic Acids Res 1988; 16: 1215.

7. Miller MP. Tools for population genetics analysis (tfpga) 13: A windows program for the analysis of allozyme and molecular population genetic data. Computer software distributed by the author; 1997.

8. Brennan JA, Boyle JO, Koch WM, Goodman SN, Hruban RH, Eby YJ, et al. Association between cigarette smoking and mutation of the p53 gene in squamous-cell carcinoma of the head and neck. N Engl J Med 1995; 332: 712-717.

9. Lichtenstein P, Holm NV, Verkasalo PK, Iliadou A, Kaprio J, Koskenvuo M, et al. Environmental and heritable factors in the causation of cancer - analyses of cohorts of twins from Sweden, Denmark, and Finland. N Engl J Med 2000; 343: 78-85.

10. Nakachi K, Hayashi S, Kawajiri K, Imai K. Association of cigarette smoking and CYP1A1 polymorphisms with adenocarcinoma of the lung by grades of differentiation. Carcinogenesis 1995; 16: 22092213.

11. Xu X, Kelsey KT, Wiencke JK, Wain JC, Christiani DC. Cytochrome P450 CYP1A1 Mspl polymorphism and lung cancer susceptibility. Cancer Epidemiol Biomarkers Prev 1996; 5: 687-692.

12. Harries LW, Stubbins MJ, Forman D, Howard GC, Wolf CR. Identification of genetic polymorphisms at the glutathione S-transferase $\mathrm{Pi}$ locus and association with susceptibility to bladder, testicular and prostate cancer. Carcinogenesis 1997; 18: 641-644.

13. Matthias C, Bockmuhl U, Jahnke V, Harries LW, Wolf CR, Jones PW, et al. The glutathione S-transferase GSTP1 polymorphism: effects on susceptibility to oral/pharyngeal and laryngeal carcinomas. Pharmacogenetics 1998; 8: 1-6.

14. Ryberg D, Skaug V, Hewer A, Phillips DH, Harries LW, Wolf CR, et al. Genotypes of glutathione transferase M1 and P1 and their signif- icance for lung DNA adduct levels and cancer risk. Carcinogenesis 1997; 18: 1285-1289.

15. Olshan AF, Weissler MC, Watson MA, Bell DA. GSTM1, GSTT1, GSTP1, CYP1A1, and NAT1 polymorphisms, tobacco use, and the risk of head and neck cancer. Cancer Epidemiol Biomarkers Prev 2000; 9: 185-191.

16. Oude Ophuis MB, van Lieshout EM, Roelofs HM, Peters WH, Manni JJ. Glutathione S-transferase M1 and T1 and cytochrome P4501A1 polymorphisms in relation to the risk for benign and malignant head and neck lesions. Cancer 1998; 82: 936-943.

17. Xie H, Hou L, Shields PG, Winn DM, Gridley G, Bravo-Otero E, et al. Metabolic polymorphisms, smoking, and oral cancer in Puerto Rico. Oncol Res 2004; 14: 315-320.

18. Park JY, Muscat JE, Ren Q, Schantz SP, Harwick RD, Stern JC, et al. CYP1A1 and GSTM1 polymorphisms and oral cancer risk. Cancer Epidemiol Biomarkers Prev 1997; 6: 791-797.

19. Hashibe M, Brennan P, Strange RC, Bhisey R, Cascorbi I, Lazarus $P$, et al. Meta- and pooled analyses of GSTM1, GSTT1, GSTP1, and CYP1A1 genotypes and risk of head and neck cancer. Cancer Epidemiol Biomarkers Prev 2003; 12: 1509-1517.

20. Katoh T, Kaneko S, Takasawa S, Nagata N, Inatomi H, Ikemura K, et al. Human glutathione S-transferase P1 polymorphism and susceptibility to smoking related epithelial cancer; oral, lung, gastric, colorectal and urothelial cancer. Pharmacogenetics 1999; 9: 165169.

21. Park JY, Schantz SP, Stern JC, Kaur T, Lazarus P. Association between glutathione S-transferase pi genetic polymorphisms and oral cancer risk. Pharmacogenetics 1999; 9: 497-504.

22. Schneider J, Bernges U, Philipp M, Woitowitz HJ. GSTM1, GSTT1, and GSTP1 polymorphism and lung cancer risk in relation to tobacco smoking. Cancer Lett 2004; 208: 65-74.

23. Abbas A, Delvinquiere $K$, Lechevrel M, Lebailly $P$, Gauduchon $P$, Launoy G, et al. GSTM1, GSTT1, GSTP1 and CYP1A1 genetic polymorphisms and susceptibility to esophageal cancer in a French population: different pattern of squamous cell carcinoma and adenocarcinoma. World J Gastroenterol 2004; 10: 3389-3393.

24. Chen K, Jiang QT, He HQ. Relationship between metabolic enzyme polymorphism and colorectal cancer. World J Gastroenterol 2005; 11: 331-335.

25. Esteller M, Corn PG, Urena JM, Gabrielson E, Baylin SB, Herman JG. Inactivation of glutathione S-transferase P1 gene by promoter hypermethylation in human neoplasia. Cancer Res 1998; 58: 45154518.

26. Lohmueller KE, Pearce CL, Pike M, Lander ES, Hirschhorn JN. Meta-analysis of genetic association studies supports a contribution of common variants to susceptibility to common disease. Nat Genet 2003; 33: 177-182.

27. Pharoah PD, Dunning AM, Ponder BA, Easton DF. Association studies for finding cancer-susceptibility genetic variants. Nat Rev Cancer 2004; 4: 850-860. 